FESIEE

Fundación Emilio Soldevilla para la Investigación y Desartollo

\section{Management Letters / Cuadernos de Gestión}

\author{
journal homepage: http://www.ehu.eus/cuadernosdegestion/revista/es/
}

ISSN: 1131-6837 / e-ISSN: 1988-2157

\title{
The assurance of sustainability reports and their impact on stock market prices
}

\section{La verificación de los informes de sostenibilidad y su impacto en los precios bursátiles}

\author{
María Mar Miralles-Quirós ${ }^{\star}$, José Luis Miralles-Quirós ${ }^{\mathrm{a}}$, Julio Daza-Izquierdo ${ }^{\mathrm{b}}$ \\ a Department of Financial Economics and Accounting - University of Extremadura - Faculty of Economics and Business Sciences, Av. Elvas s/n 06006 Badajoz. \\ - miralles@unex.es-https://orcid.org/0000-0002-6591-1783 \\ ${ }^{b}$ Department of Business Organization and Sociology - University of Extremadura - Plasencia University Center, C/ Virgen Puerto 2, 10600 Plasencia - juliodaza@unex.es - \\ https://orcid.org/0000-0001-9691-7048
}

* Corresponding author: Department of Financial Economics and Accounting - University of Extremadura - Faculty of Economics and Business Sciences, Av. Elvas s/n 06006 Badajoz.- marmiralles@unex.es - https://orcid.org/0000-0003-0255-2661

\section{A R T I C L E I N F O}

Received 15 March 2020,

Accepted 5 November 2020

Available online 11 January 2021

DOI: $10.5295 / \mathrm{cdg} .201262 \mathrm{~mm}$

JEL CODES: G10; G14

\begin{abstract}
A B S T R A C T
The publication of non-financial information is a trend in recent decades in listed companies. From this fact, the need arises to provide credibility to the information by verifying an independent professional who provides a guarantee of the published information. Therefore, this article analyses whether the verification of sustainability reports influences the stock prices of Ibex- 35 companies. With this aim, a content analysis has been prepared that allows us to quantify aspects as relevant as the commissioning and the objective of the assurance requested by the company, the auditor's independence or the result of the verification process. The results obtained show that Ibex- 35 companies maintain a growing trend in their social commitment and greater recognition of the transfer of verified information to the different stakeholders of the companies. In addition, the efforts made by companies are valued positively by investors, especially in response to the level of assurance requested from the guarantee provider of the sustainability report.
\end{abstract}

Keywords: Sustainability Reports; Assurance; Market Valuation, Ibex-35

\section{R E S U M E N}

La publicación de la información no financiera es tendencia en las últimas décadas en las empresas cotizadas. De este hecho, surge la necesidad de aportar credibilidad a la información mediante la verificación de un profesional independiente que aporte garantía de la información publicada. Por ello, en este artículo se analiza si la verificación de las memorias de sostenibilidad influye en los precios bursátiles de las empresas del Ibex-35. Con este objetivo, se ha elaborado un análisis de contenidos que nos permite cuantificar aspectos tan relevantes como el servicio y objetivo de aseguramiento exigido por la empresa, la independencia del auditor o el resultado del proceso de verificación. Los resultados obtenidos muestran que las empresas del Ibex-35 mantienen una tendencia creciente en su compromiso social y un mayor reconocimiento a la transferencia de información verificada a los distintos stakeholders de las compañías. Además, los esfuerzos realizados por las empresas son valorados positivamente por los inversores, especialmente atendiendo al nivel de aseguramiento solicitado al proveedor de garantía del informe de sostenibilidad.

Palabras clave: Informes de sostenibilidad; Verificación; Valoración bursátil; Ibex-35.

This paper has been financially supported by the Junta de Extremadura under the VI Action Plan for Research and Development 2017/20 through the GIMAF research group (reference GR18022). 


\section{INTRODUCTION}

In recent decades, the number of sustainability reports produced and published by firms to inform stakeholders of their environmental, social and corporate governance activities has increased significantly. ${ }^{1}$ This may be due to the pressure placed on firms by the different stakeholders to produce and publish this type of information. This pressure is much more direct in countries where firms have been forced to do this through legal provisions (Miras and Di Pietra 2018).

Therefore, the issue today is not whether firms publish sustainability reports or not, but the approach they have to communicating sustainability. This approach can reflect a true commitment to reporting back to stakeholders, or simply be a marketing tool to meet external demands, with the risk that the reported information will not reflect the real situation (Adams and Frost 2008).

That is why, despite the significant increase in reports published and the existence of globally recognised standards, such as the guide produced by the Global Reporting Initiative (GRI), that allow for the standardisation and subsequent comparison of sustainability information, many stakeholders question the reliability, and therefore the credibility, of the information included in these reports (Owen et al. 2000; Dando and Swift 2003; Movena et al. 2006; Michelon et al. 2015; Lock et al. 2016; El-Raham 2020; Haider and Nishitani 2020).

In this context, in which the sustainability information is questionable or lacks credibility, some firms voluntarily began a process to verify this information, sending these reports for an external quality assurance process conducted by independent experts, auditors or consultants, who must produce a declaration giving their opinion. However, this verification service leads to additional costs for reporting sustainability information, which firms will only be willing to pay if they can see that this will result in a profit.

As Simnet (2012) states, providing an external guarantee of the content and structure of sustainability reports should improve their importance, reliability and comparability. Therefore, it should generate credibility and confidence among stakeholders about the quality of the information supplied, acting as a control on managers and thus reducing uncertainty and asymmetry of information problems.

However, the fact that it is not a legal requirement is coupled with the lack of a universal standard for this assurance. ${ }^{2}$ Furthermore, it is possible to calibrate the extent to which the contents of the sustainability report are reviewed. Thus, Braam

${ }^{1}$ According to KPMG data, more than $90 \%$ of large firms published such reports in 2017.

The international standards most frequently used by assurance providers are the AA1000 Assurance Standard (AA1000AS) produced by AccountAbility and the International Standard on Assurance Engagements ISAE 3000 produced by the International Assurance and Auditing Standards Board (IAASB). These standards are not contradictory or substitutes, but rather complements in terms of contributing to providing a comprehensive and solid external assurance. Specifically, AA1000AS provides the requirements to conduct the sustainability assurance, whereas ISAE3000 provides the principles and procedures that accounting firms must follow when reviewing non-financial information (Simnett 2012; Segui-Mas et al. 2018) and Peeters (2018) noted that the voluntary assurance by third parties of sustainability reports can vary significantly in terms of the choice of the assurance provider as well as the scope and level of assurance. This all contributes to the existence of great diversity in sustainability information verification reports in terms of the objectives, extent and criteria of the assurance. This diversity leads to scepticism about the work of the assurance company, as the nature and content of assurance declarations can vary significantly (Hodge et al. 2009; Fuhrmann et al. 2017).

In this context, the literature on the assurance of sustainability information has focused on two fundamental lines of research. First, we have studies that analyse the content and quality of assurance declarations included in sustainability reports (Ball et al. 2000; Owen et al. 2000; O'Dwyer and Owen 2005; Deegan et al. 2006; Cooper and Owen 2007; Mock et al. 2007; Manetti and Becatti 2009; Manetti and Toccafondi 2012; Perego and Kolk 2012; Gürtürk and Hahn 2016; Braam and Peeters 2018). Second, we have studies that analyse the characteristics of the firms making the decision to begin an external assurance process for the sustainability information (Simnett et al. 2009; Fernández-Feijóo-Souto et al. 2012; Zorio et al. 2013; Castelo Branco et al. 2014; Cho et al. 2014; Sierra et al. 2014; Fernández-Feijóo-Souto et al. 2015; Vaz Ogando et al. 2018). Lastly, we should highlight an emerging line of research focused on analysing the reaction of the different stakeholders to obtaining sustainability report assurance (Dhaliwal et al. 2012; Romero et al. 2014; Fazzini and Dal Maso 2016; Arco-Castro et al. 2020).

The role of financial stakeholders (shareholders, analysts, professional portfolio managers and potential individual investors) is worth noting because they request a large amount of information so that they can make their financial decisions. These market participants subject listed firms to greater information disclosure pressure while demanding greater credibility in the published information. Therefore, they can use assurance as a signal for future investment decisions. This in turn may have an impact on stock market prices if stakeholders positively value having this information.

In this context, the aim of this study is to analyse whether financial stakeholders positively value the assurance process of the sustainability information of the firms in the selective index of the Spanish stock market, Ibex-35, ${ }^{3}$ for the $2011-2019$ period. For this, an analysis of the content of the verification reports for the largest and most liquid firms in the continuous Spanish market was conducted by evaluating a series of indicators that measure the quality of these verification reports as a whole, highlighting aspects as important as the commissioning and objective of the assurance requested by the company, the independence of the auditor and the result of the verification process. Secondly, the valuation model for stock market firms proposed by Ohlson $(1995,2001)$ was used to analyse whether the verification of the non-financial information provided by the firms had a significant effect on stock market prices, and therefore whether it is positively valued by the stock market.

This index is the main national and international reference for the Spanish stock market, as well as an underlying asset in a large number of financial products. 
Spain is an interesting case study because it is one of the countries most committed to disclosing sustainability information. As stated by Fernández-Feijóo-Souto et al. (2012), in 2008 Spain became the country with the largest number of Corporate Social Responsibility (CSR) reports registered in the GRI database, even ahead of countries of greater industrial strength such as the United States, Japan, Germany and France, and those with a longer tradition on CSR matters such as Switzerland, Denmark and Finland. Currently, Spanish large firms must submit CSR reports (Law 2/2011 about Sustainable Economy and Law 11/2018 about Non-Financial Information and Diversity), which is why this trend has been growing. Furthermore, the reports published by Spanish firms obtain high scores in the sustainability indexes according to KPMG (2011), Fernández-Feijóo-Souto et al. (2012) and Sierra et al. (2018), among others. Therefore, we believe that, as stated by Vaz Ogando et al. (2018), this country has reached a strong level of maturity, which makes it important to analyse the impact of the assurance service on stock market prices.

The results obtained show that during the period analysed there was a greater social commitment by firms in the Ibex-35, and a greater recognition of the transfer of verified information to the different stakeholders of the firms. This effort made by firms has been positively valued in the stock market, especially if we look at the commissioning and objective of the assurance requested by the company. This study contributes to the large existing body of research on the assurance of sustainability reports. Furthermore, our results have important implications for firms, managers, financial stakeholders, other stakeholders and public bodies directly linked to adopting corporate social responsibility and assurance measures.

The remainder of the article is structured as detailed below. The second section includes the review of the literature on the value relevance of sustainability reports as well as the assurance of sustainability information. In the third section we discuss the study methodology, dividing this into two subsections: one which includes the content analysis to quantify the content of the assurance of sustainability reports, and a second which shows the methodology used to analyse the impact on stock market prices. In section four we give the empirical results obtained. Finally, in section five we discuss the conclusions drawn from the paper as a whole.

\section{LITERATURE REVIEW}

\subsection{The value relevance of sustainability reports}

CSR disclosure has received a great deal of attention from the academia since the early evidence of Ingram and Frazier (1980) and Wiseman (1982), among others. These initial investigations focused exclusively on whether companies published CSR information or not without considering the content and reliability of these reports. Thus, there were published numerous studies centred on analysing the motives for managers to disclose CSR information (Belkaoui and Karpik 1989; Brown and Fraser 2006; Kolk 2008; Spence 2009; Baumgartner 2014) or the characteristics of companies that compile CSR reports (Secchi 2006; Brammer and Pavelin 2008; Haddock-Fraser and Fraser 2008;
Mio 2010; Gamerschlag et al. 2011). These previous studies support the view of managers that CSR disclosure contributes to increasing the credibility and trust in their companies. Moreover, previous empirical evidence showed that larger, more profitable and listed firms were those ones that started to introduce in their corporate strategy the practice of elaborating and disclosing information about their socially responsible activities.

More precisely, the practice of CSR disclosure is especially common among listed companies due to the pressure exerted by financial stakeholders who demand reliable and comparable information in order to help them when they are making their investment decisions or preparing their investment advice. Theoretically, by disclosing this information, listed companies can reduce the information asymmetries between managers and financial stakeholders (Healy and Palepu 2001) as well as their adverse selection costs (Diamond and Verrecchia 1991; Kim and Verrecchia 1994). Moreover, financial analysts can reduce their forecasting errors because this information can attenuate the stakeholders' uncertainty about firms' future economic benefits and their associated risks (Lang and Lundholm 2000; Lang and Maffett 2011). Thus, all these aspects have positive direct effects such as increasing the number of potential investors, raising more equity capital or attracting greater analyst coverage (Merton 1987). Elliott et al. (2014) and Cahan et al. (2016) also argue that CSR disclosures can produce indirect effects. This information, for instance, can contribute to providing legitimacy to the company or mitigating negative impacts when the firm or other ones in the same industry reveal controversy activities. As a consequence, it can alter investors' perceptions of firm value. We can therefore expect a positive association between CSR disclosure and the market value of companies that provide this kind of information.

However, previous empirical evidence in this field provides inconclusive results and therefore the value that market participants assign to this kind of information is not yet clear. Employing an accounting-based valuation model for companies listed on stock markets, there are initial studies that report a positive and significant relationship between CSR disclosure and firm value such as those of Moneva and Cuellar (2009) for the Spanish stock market over the 1996-2004 period, Schadewitz and Niskala (2010) for the Finish stock market over the 2002-2005 period and Berthelot et al. (2012) for the Canadian stock market in 2007. All these studies employed a similar methodology based on estimating a value relevance model that consider only accounting variables. After that, they also tested a second model in which a dummy variable that indicated whether the firm disclosed sustainability report or not was added. The comparison of these two estimates permits to test the premise developed by Ohlson $(1995,2001)$ that the accounting variables alone fail to explain firms' market value and additional non-financial information relevant for financial stakeholders is needed such as the sustainable information provided in CSR reports.

Meanwhile, other studies conclude that there is a mixed or a non-significant relationship between the information provided in CSR reports and firm value, such as those of Cormier and Magnan (2007), Carnevale et al. (2012), Bowerman and Sharman (2016) and Kaspereit and Lopatta (2016). More precisely, Cormier and Magnan (2007) analysed the value relevance 
of environmental disclosure of firms quoted on the Canadian, French and German markets. Their results revealed that this kind of information had a moderating impact on German firms' value while there was a not significant impact for firms quoted on the Canadian and French stock markets. Consequently, they suggested that national institutional contexts should be taken into account in these empirical researches. Meanwhile, Carnevale et al. (2012) analysed the specific case of the banking industry over the 2002-2008 period and their results did not provide evidence that financial stakeholders that operate on stock markets attribute a significant value to CSR disclosure. More recently, Bowerman and Sharman (2016) analysed the UK and Japan markets in 2008 and found that Japanese investors did not significantly value CSR disclosure information while UK investors positively valued this information. Moreover, Kaspereit and Lopatta (2016) analysed a sample of large European firms over the 2001-2011 period. They showed that sustainability reporting was not significantly associated with a higher market valuation. However, they did not perform a cross-country comparison in order to take into account the reaction of each stock market to this information.

On the contrary, Miralles-Quirós et al. (2017) analysed not only the overall impact of CSR disclosure on stock prices of ten European markets over the 2001-2013 period but also the effect on each market as well. Their results revealed for the entire sample that conducting businesses in accordance with sustainable norms is value relevant for financial stakeholders. However, when they provided the results for each market they noticed the absence of homogeneity among them. More interestingly, they provided evidence before and after the global financial crisis. Their results revealed that before the global financial crisis there was a significant and positive relationship between CSR disclosure practices and firm value for almost all markets. However, this relationship changed to being non-significant or negative after the global financial crisis. This evidence supports the belief that after the global financial crisis financial stakeholders do not trust CSR information provided by the companies themselves and nowadays they require more efforts by listed firms in order to increase the credibility and trust in this kind of information. Their results are supported by most recent evidence such as that provided by Camodeca et al. (2018) for a sample of large European listed firms between December, 2013 and June, 2018 as well as Kolsi and Attayah (2018) who analysed firms listed on an emerging stock market such as the ADX over the 2010-2014 period and found that CSR disclosure has no impact on firm value.

\subsection{The assurance of sustainability reports}

Studying sustainability report assurance services responds to calls by Kolk and Perego (2010) and Cohen and Simnett (2015), among others, to examine not only the adoption of sustainability reports, but also their quality and reliability. This is a prominent area of research, especially after the global financial crisis, which caused the failure of credibility and confidence in CSR information disclosed by the companies themselves (Seguí-Mas et al. 2018). Thus, there exists a huge amount of studies published in this field that can be divided in three main groups as was indicated in the introduction section.
One group of studies focuses on analysing the factors that influence the decision to begin the process for the external assurance of sustainability information. These factors can be related to the sector, country or company level such as size, being listed on the stock market or other aspects related to the economic-financial position of the company, such as its amount of leverage or its average performance for accounting or market ratios. In this group, it is worth noting the studies carried out, among others, by Simnett et al. (2009), Fernández-Feijóo-Souto et al. (2012), Zorio et al. (2013), Castelo Branco et al. (2014), Cho et al. (2014), Sierra et al. (2014), Fernández-Feijóo-Souto et al. (2015), and Vaz Ogando et al. (2018). As was expected, the overall results indicate that companies that contract this verification service and therefore accept additional costs for reporting sustainability information are those that are publicly traded, larger, more profitable and have fewer risks.

Furthermore, we have to highlight that the absence of mandatory requirements or regulations does not permit the existence of a unified procedure for professionals for the production of consistent, reliable and comparable verification reports. Thus, the result of an assurance process is a verification report or declaration whose structure and content depends on the scope of the assurance, the assurance standards and the independence of the assurance provider, among other aspects (GRI, 2013). That is why many empirical studies conducted in this line of research have focused on analysing the content and quality of the assurance declarations included in sustainability reports. Among these studies are those conducted by Ball et al. (2000), Owen et al. (2000), O'Dwyer and Owen (2005), Deegan et al. (2006), Cooper and Owen (2007), Mock et al. (2007), Manetti and Becatti (2009), Manetti and Toccafondi (2012), Perego and Kolk (2012), Gürtürk and Hahn (2016), and Braam and Peeters (2018). To that end, these authors consider that is primordial to carry out an exhaustive content analysis of the verification reports focusing on several key aspects such as the objective of the assurance service, the independence and responsibility of the auditor, the working method and the drafted conclusions in order to examine the quality of those assurance declarations.

\subsubsection{The SPecial Case of Spanish listed firms}

As we indicated in the introduction section, Spain is an interesting case study because it is one of the countries most committed to disclosing sustainability information. Consequently, this country has reached a strong level of maturity in the verification process of this information. Proof of this is the amount of studies published in the field of the verification of sustainability reports. However, these studies have focused on analysing the factors that influence the decision of companies to contract an external service for the assurance of the sustainability reports elaborated by themselves accepting additional costs.

Specifically, Fernández-Feijóo-Souto et al. (2012) analysed the characteristics of the CSR reports published by Spanish firms in 2008, as well as their assurance. Specifically, they analysed the quality of those reports according to a set of elements reported by GRI and their relationship with certain characteristics of the firms producing and publishing these reports and sending them 
for verification. Their results show that larger firms, those listed on the stock market and those commissioning a Big4 auditor are the ones with the highest quality assurance reports. ${ }^{4}$

In contrast, García-Benau et al. (2013) analysed the effect of the crisis on the tendency of firms listed on the Spanish stock market in the 2005-2010 period to produce and publish sustainability reports as well as to verify them using an external expert. Specifically, they examined whether there had been a change in their strategy for disclosing CSR and/or verifying this information. They then focused on the firms that had experienced a change in their disclosure and assurance strategy, and analysed the possible relationship between that change in strategy and the financial performance of the company, measured in accounting and market terms. The results obtained show that the number of published reports significantly increased after the financial crisis, but the number of verified reports did not significantly increase, even though the trend was also upward. Furthermore, no significant effects were detected for the financial performance of the firms.

In this same line of study, Sierra et al. (2013) analysed whether the determining factors for external assurance suggested in the international literature (industry, size, profitability, leverage) have an impact on the decision of Spanish firms to verify their CSR reports. Specifically, they focused on the CSR reports of firms in the Ibex-35 during the 2005-2010 period, and on whether these reports were verified or not. Among the main conclusions of this study, the authors highlight that the decision to submit a sustainability report to external assurance depends on certain financial variables such as size (the larger the company, the greater the propensity to verify the CSR report) and leverage (Spanish firms with a lower debt level show a greater propensity to verify CSR reports). Furthermore, it is negatively related to the return on assets and positively to the return on the company's own funds. However, they found no significant relationship with the industry or auditing company.

At the same time, Zorio et al. (2013) developed an index to measure the quality of assurance reports in Spain. The objective of this research was to identify trends in sustainability reports and especially the real assurance of this type of information. For this, they looked at firms listed on the Spanish capital market for the 2005-2010 period. Specifically, they analysed whether there are determinant variables that can affect a company's decision to publish their CSR report, to verify that report, to commission assurance services from an auditor or consultant and also the subsequent quality of the assurance report. The results obtained show that there is an increasing tendency to issue a CSR report, with the determinant factors in making this decision being the company's inclusion in the Ibex-35, the industry and whether the annual report is audited by one of the Big4. Regarding the decision to verify CSR reports, the results do not show a growing trend for this decision, although the percentage of CSR reports/verified reports is stable over time so more firms must be verifying their CSR reports, with inclusion in the Ibex-35 and the industry being determinant factors

${ }^{4}$ The term Big4 refers to the four major auditing firms: Deloitte, Ernst \& Young (EY), KPMG and PricewaterhouseCoopers (PwC). in making this decision. The same is found with other factors that can explain the decision to commission an auditor or consultant to verify the CSR report. Curiously, it was observed that no firms with annual reports audited by a company other than the Big4 verify their CSR reports. In accordance with the proposed quality index, they found that the assurance reports are of fairly acceptable quality. Only the CSR verified by an auditor (in accordance with Hodge et al., 2009) and firm size variables are significant for achieving higher quality in the assurance report.

More recently, Odriozola and Baraibar-Díez (2017) analysed whether the quality of the sustainability reports of the firms comprising the Ibex-35 for the 2006-2011 period had an impact on their subsequent corporate reputation. In light of the absence of a recognised indicator for the quality of the disclosure of sustainability information, due to the subjectivity associated with such measurement, these authors used a similar approach to the one established by Romolini et al. (2014) which takes into account the level of applicability of the international standards and assurances such as the GRI criteria and the AA1000 and ISAE3000 standards. Among the results obtained, it is worth noting the importance of the quality of the sustainability information revealed when attempting to obtain a corporate reputation. Furthermore, it is observed that the objectivity and standardisation provided by the different verification and assurance systems (especially those in the AA1000 range) are truly valued by the different stakeholders.

Lastly, we must highlight the work of Vaz Ogando et al. (2018) who analysed the sustainability report verification market in Spain, identifying the characteristics of the firms that commissioned the service as well as their strategy and attitude to the verification. For this, they conducted a survey of a sample of 342 firms registering any of their sustainability reports in the GRI database between 2001 and 2014. The results obtained by these authors show that size, sector and listing all influence the decision to verify the sustainability reports, and that the assurance strategy is focused on increasing credibility with their stakeholders.

\subsection{The value relevance of the assurance of sustainability reports}

As we indicated in the introduction section, it is expected that the provision of external assurance on the content of sustainability reports will improve their relevance, reliability and comparability. Consequently, it is also expected to generate credibility and trust among stakeholders (Simnet 2012). In this regard, it is worth highlighting a small group of studies focused on analysing the reaction of stakeholders to the assurance of sustainability reports (Dhaliwal et al. 2012; Romero et al. 2014; Fazzini and Dal Maso 2016; Arco-Castro et al. 2020).

Among these studies are those conducted by Cho et al. (2014), Fazzini and Dal Maso (2016) and Arco-Castro et al. (2020) that analyse the reaction of financial stakeholders to the assurance of sustainability reports. This line of research is especially relevant because market participants often request a large amount of information in order to reduce the problem of asymmetric information and be able to make their financial decisions. Therefore, financial stakeholders subject listed compa- 
nies to greater information disclosure pressure while demanding greater credibility in the published information. Therefore, the information provided in the assurance report is expected to have value relevance for this kind of stakeholders and to be used for their future investment decisions. This may therefore have an impact on the stock market prices of listed companies that assure their sustainability reports.

In this sense, Cho et al. (2014) examined which factors appeared to have led the US companies that did obtain assurance on their sustainability reports to do so, as well as whether this additional service was valued by financial stakeholders. Specifically, they analysed publicly traded US companies included in the 2010 Fortune 500 list, among which 217 had disclosed a standalone sustainability report that year and only 26 of them included an assurance statement. Their overall results indicated that the assurance statement was not a significant factor for the firms' market value. However, this should be taken with caution due to the fact that the sample period of this study was limited to a single year and the number of firms that adopted assurance was extremely limited. Meanwhile, they suggested that, in order to have a significant impact on the US stock market, greater effort from the assurance community to better identify the potential benefits of this service for market participants was necessary.

Later, Fazzini and Dal Maso (2016) investigated the importance of the voluntary environmental information disclosed by 48 listed Italian firms and the influence of the assurance of environmental policies during the $2008-2013$ period. Additionally, this study also analysed how the disclosure of this environmental information and its assurance were reflected in the market value of the listed Italian firms. Their results indicated that the voluntary environmental disclosure represented an important explanatory factor for the firm's market value. However, they also observed that, although approximately half of the firms analysed engaged an assurance service during the sample period, there was no incremental benefit that resulted from the assurance practice.

More recently, Arco-Castro et al. (2020) analyse how various ways of managing and securing philanthropy can affect the market value of the listed company. More specifically, these authors analyse a sample of 193 firms from 2011 to 2015. They find that the market responds positively to professional and independent management of philanthropy and welcomes external assurance of corporate philanthropy as an action that improves the perceived reliability of philanthropic activities. Thus, they conclude that corporate philanthropy and its assurance are effective signals that reduce information asymmetries between firms and investors, positively affecting the market value of companies.

Finally, it should be noted that these mixed results must be due to the fact that research in this field is extremely limited and to the simplicity of the methodology used. These studies are based exclusively on whether or not the company's sustainability practices were subject to independent assessment without considering the relevant key aspects of the assurance statements. Therefore, it is essential to provide additional evidence with new databases in order to obtain strong and conclusive results. With this work, we contribute to reduce that gap in the literature. Furthermore, we advance in this line of research by analysing the impact on prices of the content of the assurance reports. Thus, considering the arguments provided at the beginning of this subsection and previous empirical evidence, we formulate the following hypothesis:

H1) The information provided in the assurance report is value relevant for financial stakeholders and has a significant impact on stock market prices.

\section{METHODOLOGY}

\subsection{The content analysis of the assurance of sustainability reports}

The assurance of sustainability reports is an independent professional service whose objective is to decrease risk and improve the quality of the sustainability information produced and published by firms. The providers of this service must produce a verification report which is then incorporated into the sustainability report issued by the firm. However, as stated in the introduction, the absence of mandatory regulations means that there are no legal requirements or procedures that define the task of the professionals and allow for the production of consistent verification reports.

The existing literature on the assurance of sustainability reports considers the key aspects in assessing the quality of this service to be: scope of the assurance, content and drafting of the assurance report, independence of the provider, procedures used and conclusions reported (O'Dwyer and Owen 2005; Hodge et al. 2009; Gillet 2012; Herda et al. 2014).

In this context, for the purpose of analysing the quality of the assurance of the sustainability reports of the firms comprising the Ibex-35, we have conducted a content analysis of the assurance reports of the 18 firms listed on the Spanish stock market that continuously formed part of the selective index from 2011 to 2019. A total of 162 verification reports were analysed. ${ }^{5}$

In order to obtain the assurance reports, the search strategy has been based on tracking the GRI database and the websites of each of the companies under study to obtain the sustainability reports, integrated reports or the non-financial information statements published by the companies. In many cases, however, the published verification reports are not incorporated into these documents, but are found in independent documents that are difficult to find on the companies' websites.

The method used to search for and locate the verification reports has been developed in two moments in time, specifically in September 2016 and September 2020. This method of programmed search over time has allowed us to analyse the evolution of the level of assurance, something difficult to achieve in a single current search due to the impossibility of locating sustainability reports or integrated reports more than 4 years old.

5 The companies subject to the content analysis have been the listed companies of the Ibex35 during the entire period of analysis (Amadeus, Banco Sabadell, Banco Santander, Bankinter, BBVA, Caixabank, Enagás, Ferrovial, GasNatural-Naturgy, Grifols, Iberdrola, Inditex, Indra, Mapfre, Mediaset, Red Eléctrica, Repsol, Telefónica), discarding those that have experienced entries and exits from said stock market index during the period analysed. 
Table 1

Content analysis of the verification reports

\begin{tabular}{ll}
\hline No. & Indicator description \\
\hline \multicolumn{1}{c}{ A. Commissioning and objective of the assurance requested by the company }
\end{tabular}

Objective of the assurance requested by the company

0 Not indicated

1 Limited or moderate assurance

2 Mixed assurance

3 Reasonable assurance

2 Title of the assurance declaration

0 Not indicated

1 Express reference is made

3 Who the assurance declaration is aimed at

0 Not indicated

1 Internal audience

2 External stakeholders

4 Reference to the date when the sustainability information verification service ended

0 Not indicated

1 Express reference is made

5 Declaration of responsibility of the firm with regard to the request for the verification report

0 Not indicated

1 Express reference is made

\section{B. Independence and responsibility of the auditor}

6 Name of the firm providing the sustainability information verification service

0 Not indicated

1 Express reference is made

7 Location of the assurance provider

0 Not indicated

1 Express reference is made

8 Explicit declaration that the assurance provider is responsible for expressing an independent opinion on 0 Not indicated the content of the sustainability report

1 Express reference is made

9 Declaration that expresses the independence of the two parties involved: firm and assurance provider 0 Not indicated

1 Express reference is made

10 Declaration of impartiality of the assurance provider with regard to the interests of the firm's internal and external stakeholders

0 Not indicated

1 Express reference is made

11 Scope of the assurance commitment through the specification of the working methods applied

0 Not indicated

1 Shortened processes

2 Comprehensive processes

12 Description of the professional competences and skills that quality the assurance provider to conduct

0 Not indicated the assurance service

1 Express reference is made

\section{Working method and conclusions}

13 Express declaration of the criteria used in the verification on the basis of which the sustainability report 0 Not indicated has been prepared (GRI or other internal firm standards).

1 Partially described

2 There is a clear description

14 Express declaration of the use of international assurance standards (AA1000AS or ISAE3000)

0 Not indicated

1 Express reference is made

15 Declaration that explains the reasons for reaching a conclusion

0 Partially described

1 There is a clear description

16 Degree of provision of information regarding materiality. Whether the conclusion states that the report complies with the principles of AA1000

0 No reference

1 Mentioned

2 Clearly described

17 Declaration of integrity that states that all material aspects are covered by the report

0 Not indicated

1 Partially described

2 There is a clear description

18 Declaration of the firm's response capacity to identify the interests and concerns of its different stakeholders

0 Not indicated

1 Partially described

2 There is a clear description

19 Thoughts of the assurance provider about the performance

0 Not indicated

1 Express reference is made

20 Express declaration of the assurance providers about any qualifications

0 Not indicated

1 Express reference is made 
Table 1

Content analysis (Cont.)

\begin{tabular}{|c|c|c|}
\hline No. & Indicator description & Score \\
\hline \multicolumn{3}{|c|}{ C. Working method and conclusions } \\
\hline 21 & $\begin{array}{l}\text { Express description of progress made in producing the sustainability information compared to previous } \\
\text { years }\end{array}$ & $\begin{array}{l}0 \text { Not indicated } \\
1 \text { Express reference is made }\end{array}$ \\
\hline 22 & Express declaration of additional suggestions and recommendations & $\begin{array}{l}0 \text { Not indicated } \\
1 \text { Communicated to the } \\
\text { managers } \\
2 \text { Express reference is made }\end{array}$ \\
\hline 23 & Description of the scope of participation of the stakeholders in the assurance process & $\begin{array}{l}0 \text { Not indicated } \\
1 \text { Short description } \\
2 \text { There is a clear description }\end{array}$ \\
\hline
\end{tabular}

Source: Authors elaboration based on Perego and Kolk (2012) and Gurtuzrk and Hanh (2016).

Furthermore, as we can see in Table 1, the content analysis is based on the observation of 23 scoring criteria in line with Perego and Kolk (2012) and Gürtürk and Hahn (2016). Each of these scoring criteria is assigned a valuation scale depending on the level of fulfilment. The result obtained is used to generate the variable called AssuranceScore that allows us to quantify the quality of the sustainability report assurance with a maximum potential score of 33 (which take into account the aforementioned aspects).

These scoring criteria have been classified into three groups according to their nature. Thus, it allows us to group the 23 criteria of the AssuranceScore variable into three variables called FirmResp (which considers the indicators 1 to 5), AuditInd (which considers the indicators 6 to 12) and AuditResult (which considers the indicators 13 to 23 ).

More precisely, the first group of indicators refers to the commissioning and objective of the assurance requested by the firm. We believe it is essential for the verification reports analysed to explicitly give information relating to the commissioning of the assurance. That is why within this information group we have taken into account the following scoring criteria: the purpose of the commitment to assurance, the title of the assurance statement, who this statement is targeted at, the date of the report and the explicit responsibility of the company requesting it. However, as already specified by Perego and Kolk (2012) and Gürtürk and Hahn (2016), the first indicator dedicated to the assurance objective requested by the company is particularly relevant. In this regard, it should be noted that the assurance process can be carried out at a limited, reasonable or mixed level. In addition, it is the company that decides what level of assurance it wants to be provided by the guarantee provider. Therefore, companies that demand a higher level of guarantee provide greater credibility and quality to the information published.

The second group of indicators analysed in the verification reports is that concerning the independence and responsibility of the auditor. Here, we established seven scoring criteria. Firstly, we take into account whether the verification report specifies the name and reference of the auditor, its responsibility regarding the truthfulness of its report, the independence of the assurance provider from the auditing company, its impartiality regarding the stakeholders, the scope of the assurance commitment and the declaration of the auditor's professional capabilities to carry out the assurance.

Lastly, we take into account a third group of scoring criteria relating to the work method and the conclusions obtained. Specifically, we considered whether the verification report gave the criteria used to carry out the verification, as well as the internationally-recognised assurance standards, whether a detailed summary of the work performed was provided, whether it indicated the degree of compliance with the materiality principle in standard AA1000, as well as the principles of integrity and response capacity. With regard to the conclusions obtained, we took into account the following information: whether the auditor listed their views on the verification report, whether they made any type of qualification, if they analysed progress compared to the report from the previous year, if they gave any suggestions or recommendations, and whether there was clear participation by the stakeholders in the assurance process.

Table 2

Evolution of verification reports

\begin{tabular}{cccccc} 
Years & AssuranceScore & AssuranceObj & FirmResp & AuditInd & AuditResult \\
\hline 2011 & 12.94 & 0.67 & 3.67 & 4.83 & 4.44 \\
2012 & 13.39 & 0.67 & 3.67 & 5.00 & 4.72 \\
2013 & 14.61 & 0.83 & 4.00 & 5.50 & 5.11 \\
2014 & 16.11 & 1.00 & 4.56 & 6.11 & 5.44 \\
2015 & 16.67 & 1.17 & 4.83 & 6.28 & 5.56 \\
2016 & 18.67 & 1.22 & 5.17 & 7.06 & 6.44 \\
2017 & 18.89 & 1.22 & 5.28 & 7.00 & 6.61 \\
2018 & 19.56 & 1.06 & 5.72 & 6.94 & 6.89 \\
2019 & 19.06 & 1.00 & 5.56 & 6.78 & 6.72 \\
\hline
\end{tabular}

This table shows the evolution of the information provided in the verification reports of the Ibex-35 firms from 2011 to 2019. More precisely, we display the average values of the variables: assurance score (AssuranceScore), objective of assurance (ObjAssurance), responsibility of the company (FirmResp), independence of the audit firm (AuditInd) and result of the verification report (AuditResult) for the group of companies analyzed in the content analysis performed.

Source: Authors elaboration. 
Before going on to analyse the impact on stock market prices, it is interesting to examine how the level of assurance in Ibex-35 firms has evolved during the 2011-2019 period analysed. For this, in Table 2 we present the evolution of the variables: assurance score (AssuranceScore), assurance objective (AssuranceObj), firm responsibility (FirmResp), auditing firm independence (AuditInd) and verification report result (AuditResult). As we indicated previously, the Assurance Score variable refers to the 23 scoring criteria and it is divided in three groups: firm responsibility (1-5), auditing firm independence (6-12) and verification report result (13-23). Meanwhile, the variable AssuranceObj refers to the first scoring criterion that due to it especial relevance is considered independently.

As can be seen in Table 2, there is generalised growth for each of the variables examined. Specifically, the AssuranceScore variable increased for the group of listed firms as a whole from 12.94 points in 2011 to 19.06 in 2019 . According to the data found, it is interesting to note that the assurance objectives requested by listed firms have increased from 0.67 points in 2011 to 1.00 in 2019 , which entails a greater social commitment by the firms and a greater recognition of the transfer of verified information to the firms' different stakeholders. The AssuranceScore variable is broken down into the FirmResp, AuditInd, and AuditResult variables, so the sum of the values of these three variables equals the value of the AssuranceScore variable. In addition, the data corresponding to these variables show a similar positive trend, without being able to name any of them as responsible for the positive trend of the AssuranceScore variable.

\subsection{Impact on stock market prices}

In stock market practice, it can be seen that the market value of all the shares in circulation is a suitable indicator of the value of a company. That is why Ohlson $(1995,2001)$ developed a valuation model for stock market firms on the basis that the value of all the shares in circulation is a function of two types of information: i) financial information, reflected by the book value and income variables; ii) non-financial information relevant to the agents in the stock market. Therefore, he arrived at the following model:

$M V E_{i, t}=\beta_{0}+\beta_{1} B V E_{i, t}+\beta_{2} E A R N S_{i, t}+\beta_{3} v_{i, t}+\varepsilon_{i, t}$

where $M V E_{i, t}$ is the market value of the equity of company $i$ in year $t ; B V E_{i, t}^{i, t}$ is the book value of the equity of company $i$ in year $t$; $E A R N S_{i, t}$ represents the earnings of company $i$ in year $t ; v_{i, t}$ being a variable that represents other relevant non-accounting information.

This model has typically been used in research into the impact of CSR information on stock markets. This is the case for studies carried out by Schadewitz and Niskala (2010), Berthelot et al. (2012), Lourenço et al. (2012, 2014), De Klerk et al. (2015), Kaspereit and Lopatta (2016), Miralles-Quirós et al. (2017,2019), among others. Thus, following these existing works, in this study we apply the Ohlson model (1995) to estimate the importance of the assurance of sustainability reports for the firms forming part of the Ibex-35.

Specifically, we test the version proposed by Barth and Clinch (2009) which consists of scaling the variables included in the initial model using the number of shares in circulation, as this mitigates any scale effects more effectively while maintaining the financial significance of the variables being studied (Miralles-Quirós et al. 2017):

$P_{i, t}=\beta_{0}+\beta_{1}$ BVPS $_{i, t}+\beta_{2}$ EPS $_{i, t}+\beta_{3}$ AssuranceScore $_{i, t-1}+\varepsilon_{i, t}$

where $P_{i, t}$ is market value divided by the number of shares of company $i$ in year $t, B V P S_{i, t}$ is the book value divided by the number of shares of company $i$ in year $t, E_{i, t}$ represents earnings divided by the number of shares of company $i$ in year $t$, AssuranceScore $_{i, t-1}$ represents the assurance score of company $i$ in year $t-1$ according to compliance with the indicators specified in the previous subsection and obtained from the content analysis performed. Based on the aforementioned, we expect the assurance level coefficient $\beta_{3}$ to be positive and significant. This would indicate that this information is positively valued in the Spanish stock market.

However, the content analysis of the verification reports provides us with information on several aspects of the assurance process such as the commissioning and objective of the assurance requested by the firm, the independence and responsibility of the auditor and the methodology and results of the assurance process. Thus, we are interested in analysing the influence of these aspects separately on the market value of the firms, thereby determining which aspects of the assurance process are most valued in the market. In addition, as specified previously, the first scoring criterion dedicated to the assurance objective is primarily important (Ruiz-Barbadillo and Martínez-Ferrero 2020). The company decides the level of assurance (limited, reasonable or mixed) that the guarantee provider will provide. This decision then determines the company's commitment to the assurance process. For this reason, it is necessary to analyse separately whether this aspect is reflected in stock market prices. This way, we present the following regression models:

$$
\begin{aligned}
P_{i, t}= & \beta_{0}+\beta_{1} \text { BVPS }_{i, t}+\beta_{2} \text { EPS }_{i, t}+\beta_{3} \text { AssuranceObj }_{i, t-1}+\varepsilon_{i, t} \\
P_{i, t}= & \beta_{0}+\beta_{1} \text { BVPS }_{i, t}+\beta_{2} \text { EPS }_{i, t}+\beta_{3} \text { FirmResp }_{i, t-1}+\beta_{4} \text { AuditInd }_{i, t-1} \\
& +\beta_{5} \text { AuditResult }_{i, t-1}+\varepsilon_{i, t}
\end{aligned}
$$

where AssuranceObj $j_{i, t-1}$ is a variable that indicates the objective of the assurance commissioned by company $i$ in year $t-1$ from the auditing company, FirmResp $p_{i,-1}$ reflects the responsibility of company $i$ with regard to the commissioning of the verification report in year $t$-1, AuditInd ${ }_{i, t-1}$ represents the independence and responsibility of the auditor of the verification report of firm $i$ in year $t-1$, AuditResult ${ }_{i, t-1}$ represents the methodology used by the auditor and the results and conclusions of the work of the assurance of company $i$ in year $t-1$. All these variables have been produced based on compliance with the respective indicators 
obtained from the previously conducted content analysis of the verification reports. As with the first analysis, it is expected that the coefficients $\beta_{3}, \beta_{4}$ and $\beta_{5}$ associated with these variables will be positive and significant. This would indicate that these aspects of the verification report are valued by the financial stakeholders in the Spanish stock market.

As can be seen in the proposed regression models, we use a panel data methodology that consists of combining time series and cross-sectional data in a joint test. This allows us to control the individual unobservable heterogeneity (company effect) as well as the endogenous nature of the explanatory variables. The method chosen to obtain robust and efficient estimates is the Generalized Method of Moments (GMM) which is a particular method of instrumental variables. To show the overall significance of the model we present, Wald's test expressed by $F$ is performed to check the joint significance of the coefficients of the explanatory variables. To check the validity of the instruments, the Sargan test of instrument over-identification is used. ${ }^{6}$

\section{EMPIRICAL RESULTS}

In this section, we present the results obtained from testing each of the regression models proposed in the methodological section, the aim being to examine whether the market value of the firms listed on the Ibex-35 is explained by the level of assurance of the sustainability reports. To conduct this analysis, we used the Datastream database and the variables resulting from the content analysis discussed in section three above. We analysed a panel of 18 listed firms during the 2011-2019 period, obtaining a total of 162 observations.

Table 3

Summary Statistics

\begin{tabular}{|c|c|c|c|c|c|c|c|c|}
\hline \multicolumn{9}{|c|}{ Panel A. Descriptive Statistics } \\
\hline & Price & BVPS & EPS & AssuranceScore & AssuranceObj & FirmResp & AuditInd & AuditResult \\
\hline Mean & 12.619 & 6.087 & 0.725 & 16.653 & 0.981 & 4.716 & 6.166 & 5.771 \\
\hline Median & 9.342 & 4.919 & 0.550 & 16.000 & 1.000 & 5.000 & 7.000 & 4.500 \\
\hline Max & 72.800 & 19.282 & 3.650 & 28.000 & 3.000 & 7.000 & 8.000 & 15.000 \\
\hline Min & 0.985 & 1.795 & 0.000 & 0.000 & 0.000 & 0.000 & 0.000 & 0.000 \\
\hline Standard deviation & 11.263 & 3.995 & 0.606 & 6.352 & 0.635 & 1.613 & 1.966 & 3.641 \\
\hline No. Observations & 162 & 162 & 162 & 162 & 162 & 162 & 162 & 162 \\
\hline \multicolumn{9}{|c|}{ Panel B. Correlation Matrix } \\
\hline & Price & BVPS & EPS & AssuranceScore & AssuranceObj & FirmResp & AuditInd & AuditResult \\
\hline Price & 1.00 & & & & & & & \\
\hline BVPS & 0.25 & 1.00 & & & & & & \\
\hline EPS & 0.62 & 0.49 & 1.00 & & & & & \\
\hline AssuranceScore & -0.00 & 0.33 & 0.05 & 1.00 & & & & \\
\hline AssuranceObj & 0.09 & 0.30 & 0.13 & 0.59 & 1.00 & & & \\
\hline FirmResp & 0.03 & 0.19 & 0.06 & 0.84 & 0.74 & 1.00 & & \\
\hline AuditInd & 0.04 & 0.28 & 0.08 & 0.87 & 0.60 & 0.90 & 1.00 & \\
\hline AuditResult & -0.04 & 0.34 & 0.01 & 0.89 & 0.38 & 0.55 & 0.58 & 1.00 \\
\hline
\end{tabular}

This table shows in Panel A the descriptive statistics and in Panel B the correlation matrix of the variables: stock price (price), book value ratio / market value per share (BVPS), income per share (EPS) and assurance score, (AssuranceScore), objective of assurance (ObjAssurance), responsibility of the company (FirmResp), independence of the audit firm (AuditInd).

Source: Authors elaboration.

${ }^{6}$ The econometric program Eviews 8 has been used to estimate the proposed models estimated by GMM. 
In light of the characteristics of the sample, in Table 3 we present the descriptive statistics and correlation matrix. As can be seen in the table, the central values of the study variables are shown, as well as the mean and median figures, noting that the average market value per share of the sample is $€ 12.619$, the book value per share is $€ 6.087$ and earnings per share is $€ 0.725$. The AssuranceScore variable, resulting from the content analysis conducted, is characterised by having a mean of 16.653 and a median of 16 , a minimum value of zero and a maximum of 28 (out of a potential score of 33 points), obtaining a deviation of 6.352, thus finding behavioural differences between firms with regard to verification reports.

As mentioned above, the AssuranceScore variable is broken down into three variables. The descriptive statistics allow us to verify this fact, since, it can be seen how the average of the AssuranceScore variable $(16,653)$ is equal to the sum of the averages of the variables into which it is broken down, FirmResp $(4,716)$, AuditInd $(6,166)$ and AuditResult $(5,771)$.

Taking into account the AssuranceObj variable, it can be seen that the average is 0.981 and the median is 1 , which implies that the average of the companies analysed require a limited or moderate level of insurance. It should be noted that this variable takes a maximum value of 3 , which shows that one or more companies have a strong social commitment and request reasonable insurance.

According to the correlation matrix shown in Panel B of Table 3 , it should be noted that the variables used to compare Olshon's model, book value per share and income, are not very correlated. In this matrix, the AssuranceScore variable and the variables used to group the 23 criteria that form it are highly correlated.

With the most characteristic aspects of the sample used for our analysis having been presented, we can present the results obtained in the different models proposed in the previous section, which can be seen in Table 4 . This table shows the results of the proposed models, represented by equations $1,2,3$, and 4 .

Firstly, Olshon's model is estimated, confirming the existence of a positive and significant relationship both of the book value and of the income over the price of the shares. The statistics shown indicate that the estimation presents a good joint significance of the variables expressed by Wald's test and that the model is sufficiently over-identified as can be seen in the results of Sargan's test, which is advisable when estimating using the GMM. The estimates of the following equations also present similar results in their statistics.

The second column of Table 4 shows the results of testing the proposed model, indicating that the AssuranceScore variable has a positive and significant influence on the stock market prices of firms with a $99 \%$ significance level. This result shows us that investors positively value the social commitment of firms, as endorsed by the level of assurance of the sustainability reports. Therefore, we consider that the $\mathrm{H} 1$ hypothesis is not rejected. Examining the other variables, it can be seen that both book value and earnings per share also have a positive and significant influence on stock market prices and that the joint significance of the model is expressed by Wald's test, being positive and significant at $99 \%$.

The third column of Table 4 shows the results of the influence of the assurance objective (AssuranceObj) on stock market prices. Thus, it can be seen that the assurance objective has a positive and significant influence on stock market prices with a $99 \%$ significance level. This is reasonable, as the greater the assurance provided by the assurance company, the greater the credibility of the information published in the sustainability reports. Furthermore, it can be observed that book value and earnings also have a positive and significant influence with a $99 \%$ significance level.

Column 4 presents the results when the influence of firm responsibility with regard to verification report commissioning, the auditor independence and the verification report result, are considered separately. Specifically, a significant positive impact on stock market prices can be observed for information related to corporate responsibility. However, we also observe a non-significant relationship between information related to auditor independence and stock market prices. Moreover, our overall results reveal a negative and significant influence of information related to the results of the verification report on stock market prices. Although this negative relationship was not expected, it is worth mentioning that the results depend on the objective of the assurance requested. Therefore, if the objective of the assurance requested is limited, the conclusions provided in the verification report will not provide information that is relevant for investors in their decision making. Finally, we can conclude that financial stakeholders value differently the different types of information provided in the verification reports.

Table 4

Impact of verifying the sustainability information on stock market prices. Additional results (2011-2019)

\begin{tabular}{|c|c|c|c|c|}
\hline & 1 & 2 & 3 & 4 \\
\hline$B V_{i . t}$ & $\begin{array}{l}3.595^{\star \star \star} \\
(46.82)\end{array}$ & $\begin{array}{l}4.434^{\star * *} \\
(43.14)\end{array}$ & $\begin{array}{l}4.116^{\star * *} \\
(26.43)\end{array}$ & $\begin{array}{l}3.399^{* * *} \\
(11.58)\end{array}$ \\
\hline$E_{i . t}$ & $\begin{array}{c}4.864^{\star * *} \\
(414.02)\end{array}$ & $\begin{array}{l}3.384^{* * *} \\
(18.61)\end{array}$ & $\begin{array}{l}3.354^{* * *} \\
(21.69)\end{array}$ & $\begin{array}{l}4.408^{\star * *} \\
(3.37)\end{array}$ \\
\hline AssuranceScore $_{i, t-1}$ & & $\begin{array}{l}0.231^{\star * *} \\
(15.52)\end{array}$ & & \\
\hline AssuranceObj $_{i, t-1}$ & & & $\begin{array}{l}4.191^{\star * *} \\
(10.44)\end{array}$ & \\
\hline FirmResp $_{i, t-1}$ & & & & $\begin{array}{l}2.934^{\star * *} \\
(2.91)\end{array}$ \\
\hline AuditInd $_{i, t-1}$ & & & & $\begin{array}{r}-0.388 \\
(-0.69)\end{array}$ \\
\hline AuditResult $_{i, t-1}$ & & & & $\begin{array}{l}-0.686^{* * *} \\
(-3.79)\end{array}$ \\
\hline$F$ & $\begin{array}{c}136,072^{* * *} \\
(0.00)\end{array}$ & $\begin{array}{l}3,888^{* * *} \\
(0.00)\end{array}$ & $\begin{array}{c}16,936^{* * *} \\
(0.00)\end{array}$ & $\begin{array}{l}181.00^{* * *} \\
(0.00)\end{array}$ \\
\hline Sargan test & $\begin{array}{r}17.664 \\
0.34\end{array}$ & $\begin{array}{r}15.581 \\
0.41\end{array}$ & $\begin{array}{r}15.777 \\
0.39\end{array}$ & $\begin{array}{r}15.084 \\
0.30\end{array}$ \\
\hline No. Obs. & 144 & 126 & 126 & 126 \\
\hline
\end{tabular}

This table shows the results of testing the models proposed in equations $1,2,3$ and 4 . Thus, they analyse the variability of the stock market prices of firms listed on the Ibex-35 in terms of book value per share $(B V)$ and earnings per share $(E)$ in each of the equations, adding the assurance score variable (AssuranceScore) in equation 2, the assurance objective variable (AssuranceObj) in equation 3 , and the firm responsibility (FirmResp), the auditing company independence (IndAudit) and the verification report result (AuditResult) variables in equation 4. The models' goodness of fit is provided by showing the $F$ statistic that analyses the joint significance of the explanatory variables. The results of the Sargan test are also presented, which tells us whether the GMM estimators are over-identified. Finally, the number of observations used for each test is detailed. ${ }^{* * *},{ }^{* *},{ }^{*}$ represent the significance level for the influence of the explanatory variable on stock market prices at $99 \%, 95 \%$ and $90 \%$ respectively.

Source: Authors elaboration. 


\section{CONCLUDING REMARKS}

The publication of sustainability reports has been a growing trend among listed companies in recent decades. However, this does not always imply a real commitment by companies to inform stakeholders about their sustainable activities. Sometimes this practice is merely a formality to meet the demands of stakeholders. In this context, the verification reports of the sustainability information provided by the company have received great relevance. This verification is carried out by an independent expert, providing credibility to the different stakeholders about the reported information. This is particularly relevant for financial stakeholders who base their investment decisions on the stock markets on the information they obtain from companies. This is why in this study we analysed the influence on stock prices of the information provided in the verification reports. In this way we can find out how financial stakeholders value such information.

Specifically, this article has analysed whether the verification of sustainability reports influences the market prices of firms in the Ibex-35 over the 2011-2019. With this objective, a content analysis was carried out which allowed us to quantify aspects as important as the commissioning and objective of the assurance required by the company, the independence of the auditor and the result of the verification process.

The results obtained provide empirical evidence on the influence of the verification of sustainability reports on stock market prices. Specifically, it has been shown that Ibex-35 firms have experienced a growth in their social commitment and greater recognition of the need to transfer verified information to the firms' different stakeholders. Furthermore, we have observed that these efforts made by firms have been positively valued by the stock market, especially looking at the assurance objective as well as other aspect related to the commissioning of the assurance requested from the supplier of the sustainability report assurance.

These results may be of interest not only to Spanish listed firms and their managers, but also especially to the different financial stakeholders (shareholders, analysts, professional portfolio managers and potential individual investors), other stakeholders of listed firms, and the different public bodies involved in adopting measures on social corporate responsibility and assurance. Finally, from an academic point of view, this article contributes to enriching the existing literature on the quality of the verification of sustainability information through an innovative approach consisting of analysing the reaction of the different stakeholders to the verification of sustainability reports and the quality of this service.

However, before concluding our study we must point out that our main limitation is the small database employed. We believe that future research should be aimed at increasing the number of listed companies analysed not only from the Spanish stock market but also from other European markets where there is also strong pressure to produce and disclose sustainability information and thus be able to analyse the difference between them.

\section{REFERENCES}

Adams C.A. and Frost G., 2008. Integrating sustainability reporting into management practices. Accounting Forum, 32(4), 288-302. DOI: 10.1016/j.accfor.2008.05.002

Arco-Castro L., López-Pérez M.V., Pérez-López M.C. and RodríguezAriza L., 2020. How market value relates to corporate philanthropy and its assurance. The moderating effect of the business sector. Business Ethics. A European Review, 29(2), 266-281. DOI: 10.1111/ beer.12264

Ball A., Owen D.L. and Gray R., 2000. External transparency or internal capture? The role of third-party statements in adding value to corporate environmental reports. Business Strategy and the Environment, 9(1), 1-23. DOI: 10.1002/(SICI)1099-0836(200001/02)9:1<1::AIDBSE227>3.0.CO;2-H

Barth M. E. and Clinch G., 2009. Scale effects in capital markets-based accounting research. Journal of Business Finance \& Accounting, 36 (3) \& (4), 253-288. DOI: 10.1111/j.1468-5957.2009.02133.x

Baumgartner, R.J., 2014. Managing corporate sustainability and CSR: a conceptual framework combining values, strategies and instruments contributing to sustainable development. Corporate Social Responsibility and Environmental Management, 21(5), 258-271. DOI: $10.1002 /$ csr.1336

Belkaoui A. and Karpik P.G., 1989. Determinants of the corporate decision to disclose social information. Accounting, Auditing \& Accountability Journal, 2(1), 36-51. DOI: 10.1108/09513578910132240

Berthelot S., Coulmont M. and Serret V., 2012. Do Investors value sustainability reports? A Canadian study. Corporate Social Responsibility and Environmental Management, 19(6), 355-363. DOI: 10.1002/ csr. 285

Bowerman S. and Sharma U., 2016. The effect of corporate social responsibility disclosures on share prices in Japan and the UK. Corporate Ownership \& Control, 13(2), 202-216. DOI: 10.22495/ cocv13i2c1p2

Braam G. and Peeters R., 2018. Corporate sustainability performance and assurance on sustainability reports: diffusion of accounting practices in the realm of sustainable development. Corporate Social Responsibility and Environmental Management, 25(2), 164-181. DOI: $10.1002 /$ csr. 1447

Brammer S. and Pavelin S., 2008. Factors influencing the quality of corporate environmental disclosure. Business Strategy and the Environment, 17(2), 120-136. DOI: 10.1002/bse.506

Brown J. and Fraser M., 2006. Approaches and perspectives in social and environmental accounting: An overview of the conceptual landscape. Business Strategy and the Environment, 15(2), 103-117. DOI: $10.1002 /$ bse. 452

Cahan S., De Villiers C., Jeter D., Naiker V. and Van Staden C., 2016. Are CSR Disclosures Value Relevant? Cross-Country Evidence. European Accounting Review, 25(3), 579-611. DOI: 10.1080/09638180.2015.1064009

Cadomeca R., Almici A. and Sagliaschi U., 2018. Sustainability disclosure in integrated reporting: Does it matter to investors? Sustainability, 10(12), 4393. DOI: 10.3390/su10124393

Carnevale C., Mazzuca M. and Venturini S., 2012. Corporate social reporting in European banks: The effects on a firm's market value. Corporate Social Responsibility and Environmental Management, 19(3), 159-177. DOI: $10.1002 / \mathrm{csr} .262$

Castelo Branco M., Delgado C., Ferreira Gomes S. and Pereira Eugénio T.C., 2014. Factors influencing the assurance of sustainability reports in the context of the economic crisis in Portugal. Managerial Auditing Journal, 29(3), 237-252. DOI: 10.1108/MAJ-07-2013-0905 
Cho C.H., Michelon G., Patten D.M. and Roberts R.W., 2014. CSR report assurance in the USA: An empirical investigation of determinants and effects. Sustainability Accounting, Management and Policy Journal, 5(2), 130-148. DOI: 10.1108/SAMPJ-01-2014-0003

Cohen J.R. and Simnett R., 2015. CSR and assurance services: A research agenda. Auditing: A Journal of Practice \& Theory, 34(1), 59-74. https://doi.org/10.2308/ajpt-50876

Cooper S.M. and Owen D.L., 2007. Corporate social reporting and stakeholder accountability: The missing link. Accounting, Organizations and Society, 32(7-8), 649-667. DOI: 10.1016/j.aos.2007.02.001

Cormier D. and Magnam M., 2007. The revisited contribution of environmental reporting to investors' valuation of a firm's earnings: An international perspective. Ecological Economics, 62 (3) \& (4), 618-626. DOI: 10.1016/j.ecolecon.2006.07.030

Dando N. and Swift T., 2003. Transparency and assurance: Minding the credibility gap. Journal of Business Ethics, 44 (2-3), 195-200. DOI: 10.1023/A:1023351816790

De Klerk M., De Villiers C. and Van Staden C., 2015. The influence of corporate social re-sponsibility disclosure on share prices. Evidence from the United Kingdom. Pacific Accounting Review, 27(2), 208-228. DOI: 10.1108/PAR-05-2013-0047

Deegan C., Cooper B.J. and Shelly M., 2006. An investigation of TBL report assurance statements. UK and European evidence. Managerial Auditing Journal, 21(4), 329-371. DOI: 10.1108/02686900610661388

Dhaliwal D.S., Radhakrishnan S., Tsang A. and Yang Y.G., 2012. Nonfinancial disclosure and analyst forecast accuracy: international evidence on corporate social responsibility disclosure. Accounting Review, 87(3), 723-759. DOI: 10.2308/accr-10218

Diamond D.W. and Verrecchia R.E., 1991. Disclosure, liquidity, and the cost of capital. Journal of Finance, 46(4), 1325-1359. DOI: 10.1111/ j.1540-6261.1991.tb04620.x

El-Rahman, N.A., 2020. The Assurance of Sustainability Reporting: An Extra Fee or a Guarantee. En: Mateev M. and Nightingale J. eds. Sustainable Development and Social Responsibility-Volume 1. Advances in Science, Technology \& Innovation (IEREK Interdisciplinary Series for Sustainable Development). Springer. DOI: 10.1007/978-3030-32922-8_19

Elliott W.B., Jackson K.E., Peecher M.E. and White B.J., 2014. The unintended effect of corporate social responsibility performance on investors' estimates of fundamental value. The Accounting Review, 89(1), 275-302. DOI: 10.2308/accr-50577

Fazzini M. and Dal Maso L., 2016. The value relevance of "assured" environmental disclosure. The Italian experience. Sustainability Accounting, Management and Policy Journal, 7(2), 225-245. DOI: 10.1108/SAMPJ-10-2014-0060

Fernández-Feijóo-Souto B., Romero S. and Ruiz-Blanco S., 2012. Measuring quality of sustainability reports and assurance statements: characteristics of the high quality reporting companies. International Journal of Society Systems Science, 4(1), 5-27. DOI: 10.1504/ IJSSS.2012.045371

Fernández-Feijóo-Souto B., Romero S. and Ruiz-Blanco S., 2015. Multilevel Approach to Sustainability Report Assurance Decisions. Australian Accounting Review, 25(4), 346-358. DOI: 10.1111/auar.12104

Fuhrmann S., Ott C., Looks E. and Guenther T.W., 2017. The contents of assurance statements for sustainability reports and information asymmetry. Accounting and Business Research, 47(4), 369-400. DOI: 10.1080/00014788.2016.1263550

Gamerschlag R., Möller K. and Verbeeten F., 2011. Determinants of voluntary CSR disclosure: empirical evidence from Germany. Review of Managerial Science, 5(2-3), 233-262. DOI: 10.1007/s11846-010-0052-3

García-Benau M.A., Sierra-García L. and Zorio A., 2013. Financial crisis impact on sustainability reporting. Management Decision, 51(7), 1528-1542. DOI: 10.1108/MD-03-2013-0102
Gillet, C., 2012. A study of sustainability verification practices: The French case. Journal of Accounting and Organizational Change, 8(1), 62-84. DOI: 10.1108/18325911211205748

GRI, 2013. The External Assurance of Sustainability Reporting. Amsterdam: Global Reporting Initiative. https://www.globalreporting.org/ resourcelibrary/GRI-Assurance.pdf

Gürtürk A. and Hanh R., 2016. An empirical assessment of assurance statements in sustainability reports: smoke screens or enlightening information? Journal of Cleaner Production, 136(10), 30-41. DOI: 10.1016/j.jclepro.2015.09.089

Haddock-Fraser J. and Fraser I., 2008. Assessing corporate environmental reporting motivation: Differences between 'Close-to-Market' and 'Business-to-Business' companies. Corporate Social Responsibility and Environmental Management, 15(3), 140-155. DOI: 10.1002/csr.147

Haider M.B. and Nishitani K., 2020. Views of corporate managers on assurance of sustainability reporting: evidence from Japan. International Journal of Disclosure and Governance, 17, 1-19. DOI: 10.1057/ s41310-019-00070-0

Healy P.M. and Palepu K.G., 2001. Information asymmetry, corporate disclosure, and the capital markets: A review of the empirical disclosure literature. Journal of Accounting and Economics, 31(1-3), 405-440. DOI: $10.1016 /$ S0165-4101(01)00018-0

Herda D.N., Taylor M.E. and Winterbotham G., 2014. The effect of country-level investor protection on the voluntary assurance of sustainability reports. Journal of International Financial Management and Accounting, 25(2), 209-236. DOI: 10.1111/jifm.12018

Hodge K., Subramaniam N. and Stewart J., 2009. Assurance of sustainability reports: Impact on report users' confidence and perceptions of information credibility. Australian Accounting Review, 19(3), 178-94. DOI: $10.1111 /$ j.1835-2561.2009.00056.x

Ingram R.W., Frazier K.B., 1980. Environmental performance and corporate disclosure. Journal of Accounting Research, 18(2), 614-622. https://www.jstor.org/stable/2490597

Kaspereit T. and Lopatta K., 2016. The value relevance of SAM's corporate sustainability ranking and GRI sustainability reporting in the European stock markets. Business Ethics: A European Review, 25(1), 1-24. DOI: $10.1111 /$ beer.12079

Kim O. and Verrecchia R.E., 1994. Market liquidity and volume around earnings announcements. Journal of Accounting and Economics, 17(1/2), 41-67. DOI: 10.1016/0165-4101(94)90004-3

Kolk A., 2008. Sustainability, accountability, and corporate governance: Exploring multinationals' reporting practices. Business Strategy and the Environment, 17(1), 1-15. DOI: 10.1002/bse.511

Kolk A. and Perego P., 2010. Determinants of the adoption of sustainability assurance statements: an international investigation. Business Strategy and the Environment, 19(3), 182-198. DOI: 10.1002/bse.643

Kolsi M.C. and Attayah O.F., 2018. Environmental policy disclosures and sustainable development: Determinants, measure and impact on firm value for ADX listed companies. Corporate Social Responsibility and Environmental Management, 25(5), 807-818. DOI: 10.1002/csr.1496

KPMG, 2011. The KPMG survey of corporate responsibility reporting 2011. The Netherlands: KPMG International. https://www.comunicarseweb.com/sites/default/files/biblioteca/pdf//1320672202_ CR_Report_2011.pdf

Lang M. and Lundholm R., 2000. Voluntary disclosure and equity offerings: reducing information asymmetry of hyping the stock. Contemporary Accounting Research, 17(4), 623-662. DOI: 10.1506/9N45F0JX-AXVW-LBWJ

Lang M. and Maffett M., 2011. Economic effects of transparency in international equity markets: A review and suggestions for future research. Foundations and Trends in Accounting, 5(3), 175-241. 
Law 2/2011, of $4^{\text {th }}$ March, about Sustainable Economy. https://www.boe. es/eli/es/1/2011/ 03/04/2/con

Law $11 / 2018$, of $28^{\text {th }}$ December, about Non-Financial Information and Diversity. https://www.boe.es/eli/es/1/2018/12/28/11

Lock I. and Seele P., 2016. The credibility of CSR reports in Europe. Evidence from a quantitative content analysis in 11 countries. Journal of Cleaner Production, 122(20), 186-200. DOI: 10.1016/j.jclepro.2016.02.060

Lourenço I., Callen J., Branco M., Curto J. and Eugenio T., 2012. How does the market value corporate sustainability performance? Journal of Business Ethics, 108(4), 417-428. DOI: 10.1007/s10551-011-1102-8

Lourenço I., Callen J., Branco M. and Curto J., 2014. The value relevance of reputation for sustainability leadership. Journal of Business Ethics, 119(1), 17-28. DOI: 10.1007/s10551-012-1617-7

Manetti G. and Becatti L., 2009. Assurance services for sustainability reports. Standards and empirical evidence. Journal of Business Ethics, 87(1), 289-298. DOI: 10.1007/s10551-008-9809-x

Manetti G. and Toccafondi S., 2012. The role of stakeholders in sustainability reporting assurance. Journal of Business Ethics, 107(3), 363-377. DOI: $10.1007 / \mathrm{s} 10551-011-1044-1$

Merton, R., 1987. A simple model of capital market equilibrium with incomplete information. Journal of Finance, 42(3), 483-510. DOI: 10.1111/j.1540-6261.1987.tb04565.x

Michelon G., Pilonato S. and Ricceri F., 2015. CSR reporting practices and the quality of disclosure: An empirical analysis. Critical Perspectives on Accounting, 33, 59-78. DOI: 10.1016/j.cpa.2014.10.003

Mio, C., 2010. Corporate social reporting in Italian multi-utility companies: An empirical analysis. Corporate Social Responsibility and Environmental Management, 1(5), 247-271. DOI: 10.1002/csr.213

Miralles-Quirós M.M., Miralles-Quirós J.L. and Arraiano I.G., 2017. Are firms that contribute to sustainable development valued by investors? Corporate Social Responsibility and Environmental Management, 24 (1), 71-84. DOI: 10.1002/csr.1392

Miralles-Quirós M.M., Miralles-Quirós J.L. and Redondo-Hernández J., 2019. The impact of ESG performance on stock prices: Evidence from the banking industry. Corporate Social Responsibility and Environmental Management, 26(6), 1446-1456. DOI: 10.1002/csr.1759

Miras M.M. and Di Pietra R., 2018. Corporate Governance mechanisms as drivers that enhance the credibility and usefulness of CSR disclosure. Journal of Management and Governance, 22(3), 565-588. DOI: 10.1007/s10997-018-9411-2

Mock T.J., Strohm C. and Swartz K.M., 2007. An examination of worldwide assured sustainability reporting. Australian Accounting Review, 17(41), 67-77. DOI: 10.1111/j.1835-2561.2007.tb00455.x

Moneva J.M., Archel P. and Correa C., 2006. GRI and the camouflaging of corporate unsustainability. Accounting Forum, 30(2), 121-137. DOI: $10.1016 /$ j.accfor.2006.02.001

Moneva J.M. and Cuellar B., 2009. The value relevance of financial and non-financial environmental reporting. Environmental and Resource Economics, 44(3), 441-456. DOI: 10.1007/s10640-009-9294-4

Odriozola M.D. and Baraibar-Diez E., 2017. Is Corporate Reputation Associated with Quality of CSR Reporting? Evidence from Spain. Corporate Social Responsibility and Environmental Management, 24(2), 121-132. DOI: 10.1002/csr.1399

O'Dwyer B. and Owen D.L., 2005. Assurance statement practice in environmental, social and sustainability reporting: A critical evaluation. The British Accounting Review, 37(2), 205-29. DOI: 10.1016/j. bar.2005.01.005

Ohlson, J.A., 1995. Earnings, book values and dividends in equity valuation. Contemporary Accounting Research, 11(2), 661-686. DOI: 10.1111/j.1911-3846.1995.tb00461.x

Ohlson, J.A., 2001. Earnings, book values and dividends in equity valuation: An empirical perspective. Contemporary Accounting Research, 18(1), 107-120. DOI: 10.1506/7TPJ-RXQN-TQC7-FFAE
Owen D.L., Swift T.A., Humphrey C. and Bowerman M., 2000. The New Social Audits: Accountability, Managerial Capture or the Agenda of Social Champions? European Accounting Review, 9(1), 81-98. DOI: $10.1080 / 096381800407950$

Perego P. and Kolk A., 2012. Multinationals' Accountability on Sustainability: The Evolution of Third-party Assurance of Sustainability Reports. Journal of Business Ethics, 110(2), 173-190. DOI: 10.1007/ s10551-012-1420-5

Romero S., Fernández-Feijoo B. and Ruiz S., 2014. Perceptions of quality of assurance statements for sustainability reports. Social Responsibility Journal, 10(3), 480-499. DOI: 10.1108/SRJ-10-2012-0130

Romolini A., Fissi S. and Gori E., 2014. Scoring CSR reporting in listed companies - Evidence from Italian best practices. Corporate Social Responsibility and Environmental Management, 21(2), 65-81. DOI: 10.1002/csr.1299

Ruiz-Barbadillo E. and Martínez-Ferrero J., 2020. What impact do countries have on levels of sustainability assurance? A complementarysubstitutive perspective. Corporate Social Responsibility and Environmental Management, 27(5), 2329-2341. DOI: 10.1002/csr.1967

Schadewitz H. and Niskala M., 2010. Communication via responsibility reporting and its ef-fect on firm value in Finland. Corporate Social Responsibility and Environmental Management, 17(2), 96-106. DOI: $10.1002 /$ csr.234

Secchi, D., 2006. The Italian experience in social reporting: An empirical analysis. Corporate Social Responsibility and Environmental Management, 13(3), 135-149. DOI: 10.1002/csr.96

Seguí-Mas E., Polo-Garrido F. and Bollas-Araya H.M., 2018. Sustainability Assurance in Socially-Sensitive Sectors: A Worldwide Analysis of the Financial Services Industry. Sustainability, 10(8), 2777. DOI: $10.3390 /$ su10082777

Sierra L., Zorio A. and García-Benau M.A., 2013. Sustainable Development and Assurance of Corporate Social Responsibility Reports Published by Ibex-35 Companies. Corporate Social Responsibility and Environmental Management, 20(6), 359-370. DOI: 10.1002/ csr. 1303

Sierra L., García-Benau M.A. and Zorio A., 2014. Credibilidad en Latinoamérica del informe de Responsabilidad Social Corporativa. Revista de Administração de Empresas, 54(1), 28-38. DOI: 10.1590/ S0034-759020140104

Sierra-García L., García-Benau M.A. and Bollas-Araya H.M., 2018. Empirical Analysis of Non-Financial Reporting by Spanish Companies. Administrative Sciences, 8(3), 29. DOI: 10.3390/admsci8030029

Simnett, R., 2012. Assurance of sustainability reports. Revision of ISAE 3000 and associated research opportunities. Sustainability Accounting, Management and Policy Journal, 3(1), 89-98. DOI: $10.1108 / 20408021211223570$

Simnett R., Vanstraelen A. and Chua W.F., 2009. Assurance on sustainability reports: An international comparison. Accounting Review, 84(3), 937-67. DOI: 10.2308 /accr.2009.84.3.937

Spence, C., 2009. Social and environmental reporting and the corporate ego. Business Strategy and the Environment, 18(4), 254-265. DOI: $10.1002 /$ bse. 600

Vaz Ogando N., Ruiz Blanco S. and Fernández-Feijoo Souto B., 2018. El mercado de verificación de las memorias de sostenibilidad en España: un análisis desde la perspectiva de la demanda. Revista de Contabilidad, 21(1), 48-62. DOI: 10.1016/j.rcsar.2017.07.003

Wiseman, J., 1982. An evaluation of environmental disclosures made in corporate annual reports. Accounting, Organizations and Society, 7(1), 53-63. DOI: 10.1016/0361-3682(82)90025-3

Zorio A., García-Benau M.A. and Sierra L., 2013. Sustainability Development and the Quality of Assurance Reports: Empirical Evidence. Business Strategy and the Environment, 22(7), 484-500. DOI: 10.1002/bse.1764 